\title{
STRATEGI PENGEMBANGAN BANK SAMPAH DI KABUPATEN PATI
}

\section{THE STRATEGY OF TRASH BANK DEVELOPMENT IN PATI REGENCY}

\author{
Iwan Riswana $^{1)^{*}}$, Didi Rukmana ${ }^{2)}$, Sitti Bulkis ${ }^{2)}$ \\ ${ }^{1)}$ Dinas Lingkungan Hidup Kabupaten Pati \\ ${ }^{2)}$ Prodi Perencanaan dan Pengembangan Wilayah Universitas Hasanuddin \\ *Email : iwan.riswana@yahoo.co.id
}

\begin{abstract}
Trash bank is a place for sorting and collecting of trash that can be recycled or reused which has economic value. This research aimed to formulate the strategy of trash bank development in the settlement of Pati Regency. This research used descriptive method with quantitative and qualitative approach (mix method). The data were collected through observation, interviews, and document study. The research was conducted in Pati Regency. The result indicates that the sustainability level of trash bank in Pati Regency is at 60\%. It means that the trash bank system is considered normal. There are 6 groups which are influential and have interests in the trash banks that are Environmental Office of Pati Regency, Village Government, customers, collectors, scavengers and the community. The main strategies that can be used in the development of trash banks are: 1) encouraging Environmental Office of Pati Regency to provide training and ready to accommodate and to buy the trash products; 2) Along with village government, environmental office conduct socialization of proper waste management and optimization of waste bank management.
\end{abstract}

Keywords: aspects of sustainability, trash bank, development strategy

\section{ABSTRAK}

Bank sampah adalah tempat pemilahan dan pengumpulan sampah yang dapat didaur ulang dan atau diguna ulang yang memiliki nilai ekonomi. Tujuan penelitian ini adalah mencari strategi pengembangan bank sampah pemukiman di Kabupaten Pati. Penelitian ini berjenis penelitian deskriptif dengan pendekatan kuantitatif dan kualitatif. Penelitian dilakukan di Kabupaten Pati. Pengumpulan data dilakukan melalui observasi, wawancara, dan telaah dokumen. Data diolah dan dianalisis dengan metode deskriptif. Hasil penelitian menunjukkan aspek keberlanjutan bank sampah di Kabupaten Pati berada pada angka $60 \%$ yang berarti sistem bank sampah dianggap wajar. Terdapat enam kelompok yang berpengaruh dan berkepentingan terhadap bank sampah, yaitu Dinas Lingkungan Hidup Kabupaten Pati, pemerintah desa, nasabah, pengepul, pemulung dan masyarakat. Strategi utama yang dapat digunakan dalam pengembangan bank sampah adalah : 1) mendorong Dinas Lingkungan Hidup Kabupaten Pati untuk memberikan pelatihan dan siap menampung serta membeli produk kerajinan sampah; dan 2) bersama Pemerintah Desa melakukan sosialisasi terkait pengelolaan sampah dan pengoptimalan manajemen bank sampah.

Kata kunci : bank sampah, aspek keberlanjutan, strategi pengembangan. 


\section{PENDAHULUAN}

Dalam Peraturan Daerah Kabupaten Pati No 7 tahun 2010 tentang pengelolaan sampah disebutkan bahwa setiap orang berkewajiban mengurangi timbulan sampah, memilah sampah dari sumbernya dan melakukan pengolahan sampah yang berwawasan lingkungan. Salah satu metode untuk mengurangi sampah mulai dari sumbernya adalah melalui pendirian bank sampah. Bank sampah merupakan institusi yang didirikan masyarakat untuk mengelola sampah dan memperoleh manfaat ekonomi dari sampah dengan mekanisme menabung sampah yang dapat didaur ulang dan masih memiliki nilai ekonomi.

Di Kabupaten Pati terdapat 33 bank sampah pemukiman yang berdiri sampai dengan tahun 2016. Pendirian bank sampah tidak lepas dari dukungan Pemerintah daerah dalam rangka mewujudkan kondisi zero waste dan menunjang Kota Pati sebagai Kota Adipura. Pemerintah Kabupaten Pati merencanakan untuk mendirikan minimal satu bank sampah pada 21 desa yang masuk wilayah pengembangan kota.

Namun sejak dimulainya program bank sampah pada tahun 2013, dari 21 desa yang menjadi target pendirian bank sampah masih terdapat beberapa desa yang belum memiliki bank sampah. Hal ini disebabkan masih rendahnya peran serta masyarakat dalam pengelolaan sampah. Selain itu, bank sampah yang sudah berdiri juga masih mendapatkan permasalahan-permasalahan dalam menjalankan kegiatannya. Masalah utama yang dihadapi oleh para pengelola bank sampah adalah tidak stabilnya harga penjualan sampah daur ulang (recyclable waste).
Menurut Kristina (2014), keberlanjutan pengelolaan sistem bank sampah hanya akan terjadi jika sistem bank sampah dirawat oleh para stakeholder yang terkait dengan sistem pemberdayaan masyarakat. Apabila tidak dilakukan perencanaan yang matang dan pelaksanaan yang tidak terarah maka suatu saat program tersebut dapat berhenti. Faktor- faktor keberlangsungan bank sampah meliputi pelibatan semua komponen masyarakat, kerjasama menguntungkan antara pengelola bank sampah dengan pengepul sampah, penyuluhan dan sosialisasi terus menerus, memberikan penghargaan (reward system) bagi penabung terbanyak (Suwerda, 2012).

Tujuan penelitian ini adalah menganalisis tingkat keberlanjutan bank sampah dan memformulasikan strategi pengembangan untuk meningkatkan tingkat keberlanjutan bank sampah di Kabupaten Pati.

\section{TINJAUAN PUSTAKA}

\section{Definisi dan Jenis Sampah}

Sampah menurut kamus
lingkungan (Mustofa, 1997) adalah bahan yang tidak mempunyai nilai atau tidak berharga untuk maksud biasa atau utama dalam pembikinan atau pemakaian, barang rusak atau cacat dalam pembikinan (manufaktur), atau materi berlebihan atau ditolak atau buangan. Sampah dalam ilmu kesehatan lingkungan sebenarnya hanya sebagian dari benda atau hal-hal yang dipandang tidak digunakan, tidak dipakai, tidak disenangi, atau harus dibuang, sedemikian rupa sehingga tidak sampai mengganggu kelangsungan hidup. Dari segi ini dapat disimpulkan bahwa yang dimaksud dengan sampah ialah sebagian 
dari sesuatu yang tidak dipakai, disenangi atau sesuatu yang harus dibuang, yang umumnya berasal dari kegiatan yang dilakukan oleh manusia (termasuk kegiatan industri), tetapi yang bukan biologis (karena human waste tidak termasuk didalamnya) dan umumnya bersifat padat.

Sucipto (2012) menjelaskan jenisjenis sampah secara rinci sebagai berikut: (i) sampah organik, yaitu sampah yang berasal dari makhluk hidup, baik manusia, hewan maupun tumbuhan. Sampah organik sendiri dibagi menjadi sampah organik basah dan sampah organik kering; (ii) Sampah Anorganik, yaitu sampah yang bukan berasal dari makhluk hidup; (iii) Sampah B3 (Bahan Berbahaya dan Beracun), yaitu jenis sampah yang dikategorikan beracun dan berbahaya bagi manusia. (Sucipto, 2012)

\section{Bank Sampah}

Bank sampah adalah suatu sistem pengelolaan sampah kering secara kolektif dengan mendorong masyarakat untuk berperan aktif di dalamnya. Sistem ini menampung, memilah, dan menyalurkan sampah bernilai ekonomi pada pasar sehingga masyarakat mendapat keuntungan ekonomi dari menabung sampah. Definisi bank sampah menurut Peraturan Menteri Negara Lingkungan Hidup Republik Indonesia (Permen LH) Nomor 13 Tahun 2012 adalah tempat pemilahan dan pengumpulan sampah yang dapat didaur ulang dan/atau diguna ulang yang memiliki nilai ekonomi.

Semua kegiatan di bank sampah dilakukan dari, oleh dan untuk masyarakat. Bank sampah memiliki sistem manajerial yang operasionalnya dilakukan oleh masyarakat. Bank sampah bahkan bisa juga memberikan manfaat ekonomi untuk masyarakat. Sampah yang disetor nasabah sudah harus terpilah. Persyaratan ini mendorong masyarakat untuk memisahkan dan mengelompokkan sampah, misalnya berdasarkan jenis material: plastik, kertas, kaca, dan logam (Utami, 2013).

Bank sampah merupakan salah satu metode alternatif untuk mengajak warga peduli sampah dengan sistem pengelolaan sampah berbasis rumah tangga. Warga yang berhasil memilah dan menyetorkan sampah akan mendapatkan uang tunai dalam bentuk tabungan. Konsep bank sampah mulai banyak diterapkan di Indonesia, dimana masyarakat dapat membawa sampah tertentu lalu bisa diolah menjadi bahan yang bermanfaat.

Pelaksanaan bank sampah
sesungguhnya mengandung nilai
ekonomi (economic opportunity)
kerakyatan yang cukup tinggi karena kegiatan bank sampah dapat memberikan output nyata bagi masyarakat dalam kesempatan kerja (job creation), penghasilan tambahan bagi pegawai bank sampah dan masyarakat penabung (nasabah) dan yang paling terpenting lingkungan terjaga dengan baik terbebas dari sampah, penyakit malaria, sumber penyakit lainnya dan terbebas dari banjir/genangan serta tekanan volume sampah terhadap Tempat Pembuangan Akhir (TPA) semakin berkurang sehingga umur TPA bisa lebih panjang (Sucipto, 2012).

\section{Keberlanjutan}

Menurut Kristina (2014), keberlanjutan didefinisikan sebagai potensi untuk mengurangi resiko jangka panjang yang terkait dengan penipisan sumber daya, fluktuasi biaya energi, kewajiban produk, dan polusi dan pengelolaan limbah.

Sedangkan menurut Sarosa dalam Abadi (2013), definisi keberlanjutan ialah keberlanjutan pembangunan merupakan sebuah proses pembangunan, 
baik berupa lahan, kota, bisnis, masyarakat dan lain sebagainya dengan prinsip memenuhi kebutuhan sekarang tanpa mengorbankan kebutuhan generasi masa depan dengan menjunjung tiga aspek, yaitu memperbaiki kerusakan lingkungan tanpa mengorbankan kebutuhan pembangunan ekonomi dan keadilan sosial.

Terdapat tiga aspek utama dalam pembangunan berkelanjutan, yaitu aspek ekonomi, sosial, dan lingkungan. Lebih khusus, aspek lingkungan dalam keberlanjutan pengelolaan bank sampah dapat ditinjau dari kemampuan bank sampah dalam mengurangi timbulan sampah. Dalam Peraturan Menteri Lingkungan Hidup (Permen LH) No. 13 tahun 2013 dinyatakan keberadaan bank sampah diharapkan mampu mengurangi sampah yang diangkut ke TPA sebesar $30-40 \%$ setiap bulannya.

Aspek keberlanjutan ekonomi pengelolaan bank sampah dapat ditinjau dengan mengetahui perbandingan total biaya yang dikeluarkan untuk menjalankan bank sampah dengan total pemasukan yang diperoleh dari hasil pengelolaan bank sampah (Abadi, 2013). Untuk itu data mengenai harga beli sampah dari nasabah, harga jual sampah dari pengelola bank sampah kepada pengepul serta keuntungan ekonomi dari nasabah perlu untuk diketahui (Apriliyanti dkk., 2015).

Aspek keberlanjutan secara sosial menekankan pada adanya keterlibatan masyarakat dalam pengelolaan sampah dari sumbernya. Lebih rinci, Abadi (2013) memberikan beberapa kriteria keberlanjutan bank sampah secara sosial meliputi : 1) Keterlibatan masyarakat dalam pemilahan sampah di sumber; 2) Keterlibatan masyarakat dalam pengolahan sampah dengan konsep 3R; 3) Keterlibatan masyarakat dalam mematuhi aturan pembuangan sampah yang ditetapkan; dan 4) Keterlibatan masyarakat dalam menjaga kebersihan lingkungan dan sekitarnya.

\section{Penelitian Terdahulu}

Beberapa penelitian mengenai pengelolaan bank sampah telah dilakukan antara lain oleh Purwanti dkk (2015) yaitu tentang perencanaan bank sampah dalam rangka pemberdayaan masyarakat di Kecamatan Kepanjen Kabupaten Malang. Hasil studi menunjukkan bahwa peran pemerintah dalam mengawal bank sampah adalah faktor penting hingga akhirnya dapat menjadi mandiri dalam pengelolaan Bank Sampahnya. Menurut Asteria \& Heruman (2016), bank sampah adalah alternatif strategi pengelolaan sampah berbasis masyarakat di Tasikmalaya. Hasil penelitian itu menyatakan bank sampah memberikan manfaat secara ekonomi dan lingkungan terhadap masyarakat sekitar sehingga terwujud komunitas yang lebih bersih, hijau, nyaman, sehat dan sejahtera.

Anggraini dkk (2015), melakukan penelitian tentang strategi inovatif pengelolaan sampah rumah tangga perkotaan di Kota Kediri. Hasil penelitian tersebut menunjukkan bahwa terdapat beberapa faktor pendukung keberhasilan pengelolaan bank sampah, antara lain yaitu adanya keterlibatan anggota masyarakat, adanya sarana prasana dan kerjasama dengan pemerintah. Sedangkan faktor-faktor yang menghambat keberhasilan pengelolaan bank sampah, antara lain yaitu adanya beberapa masyarakat yang belum dapat berubah serta adanya ketidak siapan pengelola bank sampah dalam mengambil sampah.

Sistem bank sampah bisa berkembang menjadi unit simpan pinjam, unit usaha sembako, koperasi dan pinjaman modal usaha. Perluasan fungsi bank sampah ini bisa disesuaikan dengan kebutuhan masyarakat. Misalnya, jika 
kebanyakan masyarakat adalah wirausaha, pengembangan bank sampah diarahkan untuk unit pinjaman modal usaha. Salah satu bentuk bantuan dari organisasi masyarakat antara lain dalam pengurusan badan hukum koperasi (Mallongi \& Saleh, 2015).

\section{METODE PENELITIAN}

\section{Lokasi dan Rancangan Penelitian}

Penelitian ini dilaksanakan selama 3 bulan yakni bulan Maret-Mei 2017 di Kabupaten Pati. Penelitian ini merupakan penelitian deskriptif dengan pendekatan kuantitatif dan kualitatif (mix method). Pendekatan kuantitatif digunakan untuk mendeskripsikan aspek keberlanjutan (aspek ekonomi dan reduksi sampah) dari bank sampah, sedangkan pendekatan kualitatif digunakan untuk aspek keberlanjutan sosial budaya, lingkungan dan dukungan kebijakan serta mendeskripsikan pengelolaan bank sampah di Kabupaten Pati.

\section{Jenis dan Metode Pengumpulan Data}

Penelitian ini menggunakan data primer dan sekunder. Data primer merupakan data diambil langsung di lokasi penelitian. Data primer diperoleh dengan metode: 1) wawancara dilakukan secara terstruktur dengan panduan wawancara agar diperoleh data kualitatif yang memadai. Wawancara dilakukan dengan pengurus, nasabah, pengepul, Pemdes atau tokoh masyarakat, pejabat dari instansi terkait (DLH) untuk memperoleh informasi mengenai kondisi bank sampah serta arahan ke depan dari masing-masing stakeholder; 2) observasi yaitu melakukan pengamatan terhadap lingkungan bank sampah dan pengelolannya untuk memperkuat dan mendukung hasil wawancara sehingga diperoleh gambaran yang komprehensif terkait aspek keberlanjutannya.

Data sekunder diperoleh dengan mengumpulkan, mempelajari dan menganalisis laporan dari pengurus bank sampah dan instansi DLH Kabupaten Pati serta dari hasil pustaka, media internet dan dari hasil penelitian terdahulu. Data kuantitatif diperoleh dari laporan keuangan dan laporan reduksi sampah di 10 Bank Sampah (Tabel 1).

Tabel 1.

Gambaran Lokus Penelitian Bank Sampah

\begin{tabular}{cllccc}
\hline No & Nama Bank & Alamat & Tahun & \multicolumn{2}{c}{ Jumlah (orang) } \\
\cline { 4 - 6 } & Sampah & & Berdiri & Pengurus & Nasabah \\
\hline 1. & Asri Raharjo & Ds. Kutoharjo Kec. Pati & 2013 & 5 & 183 \\
2. & Kencana & Ds. Sidokerto Kec. Pati & 2013 & 11 & 50 \\
3. & Geritan Asri & Ds. Geritan Kec. Pati & 2014 & 10 & 61 \\
4. & Daur Kencana I & Ds. Winong Kec. Pati & 2014 & 6 & 63 \\
5. & Melati & Ds. Muktiharjo Kec. Margorejo & 2014 & 5 & 53 \\
6. & Kusuma Harum & Ds. Kutoharjo Kec. Pati & 2014 & 7 & 74 \\
7. & Berani Maju & Ds. Tambaharjo Kec. Pati & 2015 & 5 & 45 \\
8. & Sabilul Muhtadin & Ds. Muktiharjo Kec. Margorejo & 2015 & 2 & 60 \\
9. & Pijara & Ds.Tamansari Kec. Tlogowungu & 2016 & 8 & 53 \\
10. & Suka Maju & Ds. Sukoharjo Kec. Margorejo & 2016 & 20 & 95 \\
\hline Sunnyyyy
\end{tabular}

Sumber : Dinas Lingkungan Hidup Kab. Pati, 2017

\section{Teknik Analisis}

Keberlanjutan bank sampah dianalisis secara deskriptif kuantitatif dan kualitatif terhadap aspek lingkungan, aspek ekonomi dan aspek sosial budaya.
Analisis keberlanjutan bank sampah pada aspek lingkungan ditinjau dengan menganalisis efektifitas bank sampah dalam mengurangi sampah, dengan cara menghitung jumlah sampah yang 
dikelola oleh bank sampah di tahun 2016 dibandingkan dengan total timbulan sampah pada tahun yang sama (Permen LH No. 13 tahun 2013). Analisis aspek keberlanjutan ekonomi, dilakukan dengan melakukan perhitungan terhadap pendapatan bank sampah dan biaya operasional kemudian melakukan analisis kelayakan usaha (Abadi, 2013). Analisis aspek sosial budaya, dilakukan dengan menilai keterlibatan pengurus, nasabah, tokoh masyarakat/Pemdes dan masyarakat dalam pengelolaan bank sampah (Abadi, 2013)

Peran stakeholder dalam pengembangan bank sampah di Kabupaten Pati dapat diketahui melalui analisis stakeholder secara deskriptif kualitatif. Teori Miles dan Huberman digunakan untuk menganalisis data terkait dengan peran stakeholder dimana pengumpulan data dan analisis data dilakukan bersamaan secara interaktif, melalui proses: data collection, data reduction, data display dan verification/ conclusion (Usman \& Akbar, 2009).

Analisis Strength, Weakness, Opportunity, Threats (SWOT) terhadap kondisi bank sampah digunakan sebagai dasar untuk melakukan formulasi strategi pengembangan bank sampah. Perumusan strategi pengembangan bank sampah dalam penelitian ini dilakukan dengan analisis faktor internal yang meliputi kekuatan (strength) dan kelemahan (weakness), serta faktor eksternal meliputi peluang (opportunity) dan ancaman (threats).

\section{HASIL DAN PEMBAHASAN}

\section{Keberlanjutan Bank Sampah}

Hasil penelitian ini menunjukkan aspek keberlanjutan bank sampah Kabupaten Pati berada pada angka $60 \%$. Hal ini berarti sistem Bank Sampah dianggap wajar tapi menunjukkan ada ruang yang besar untuk memperbaiki program bank sampahnya. seperti ditunjukkan pada Tabel 2 .

Tabel 2.

Persentase keberlanjutan Bank Sampah

\begin{tabular}{ll}
\hline Aspek & Nilai \\
\hline Lingkungan & $80 \%$ \\
Sosial Budaya & $60 \%$ \\
Ekonomi & $40 \%$ \\
Rata-Rata & $60 \%$ \\
\hline
\end{tabular}

Sumber : Pengolahan data, 2017

Berdasarkan rata-rata persentase nilai tiga aspek, nilai keberlanjutan bank sampah Kabupaten Pati sebesar $60 \%$. Hal ini berarti sistem bank sampah dianggap wajar tapi menunjukan masih ada ruang yang besar untuk peningkatan terutama dalam program bank sampahnya (Tabel 3).

Tabel 3.

Indikator Penilaian Aspek keberlanjutan.

\begin{tabular}{|c|c|c|}
\hline Indikator warna & Tingkat keberlanjutan & Keterangan \\
\hline $\begin{array}{l}\text { Merah } \\
\text { (tak mampu beradaptasi) }\end{array}$ & $\begin{array}{l}\text { Aspek keberlanjutan } \\
<40 \%\end{array}$ & $\begin{array}{l}\text { Sistem bank sampah dianggap sangat } \\
\text { rendah dan sukar untuk ditingkatkan }\end{array}$ \\
\hline $\begin{array}{l}\text { Orange (kurang mampu } \\
\text { beradaptasi) }\end{array}$ & $\begin{array}{l}\text { Aspek keberlanjutan } \\
\text { mencapai angka } 40 \%\end{array}$ & $\begin{array}{l}\text { Sistem bank sampah dianggap rendah, tapi } \\
\text { masih ada ruang untuk meningkatkannya. }\end{array}$ \\
\hline $\begin{array}{l}\text { Kuning (cukup mampu } \\
\text { beradaptasi) }\end{array}$ & $\begin{array}{l}\text { Aspek keberlanjutan } \\
\text { mencapai angka } 60 \%\end{array}$ & $\begin{array}{l}\text { Sistem bank sampah dianggap wajar tapi } \\
\text { menunjukan ada ruang yang besar untuk } \\
\text { perbaikan }\end{array}$ \\
\hline $\begin{array}{l}\text { Hijau muda (mampu } \\
\text { beradaptasi) }\end{array}$ & $\begin{array}{l}\text { Aspek keberlanjutan } \\
\text { mencapai angka } 85 \%\end{array}$ & $\begin{array}{l}\text { Sistem bank sampah dianggap kelas } \\
\text { nasional }\end{array}$ \\
\hline $\begin{array}{l}\text { Hijau tua (sangat mampu } \\
\text { beradaptasi }\end{array}$ & $\begin{array}{l}\text { Aspek keberlanjutan } \\
\text { mencapai angka } 100 \%\end{array}$ & Sistem bank sampah dianggap sempurna \\
\hline
\end{tabular}

Sumber: Kristina, 2014 


\section{Peran Stakeholder}

Menurut Suharto (2005), stakeholder merupakan individu, kelompok maupun badan yang terpengaruh oleh program atau kebijakan. Oleh karena itu perlu diidentifikasi terlebih dahulu pihak-pihak yang terkait dengan pengembangan bank sampah di
Kabupaten Pati. Berdasarkan stakeholder mapping terdapat 6 kelompok yang berpengaruh dan berkepentingan terhadap bank sampah yaitu DLH, Pemdes, nasabah, pengepul, pemulung dan masyarakat, seperti ditampilkan pada Gambar 1.

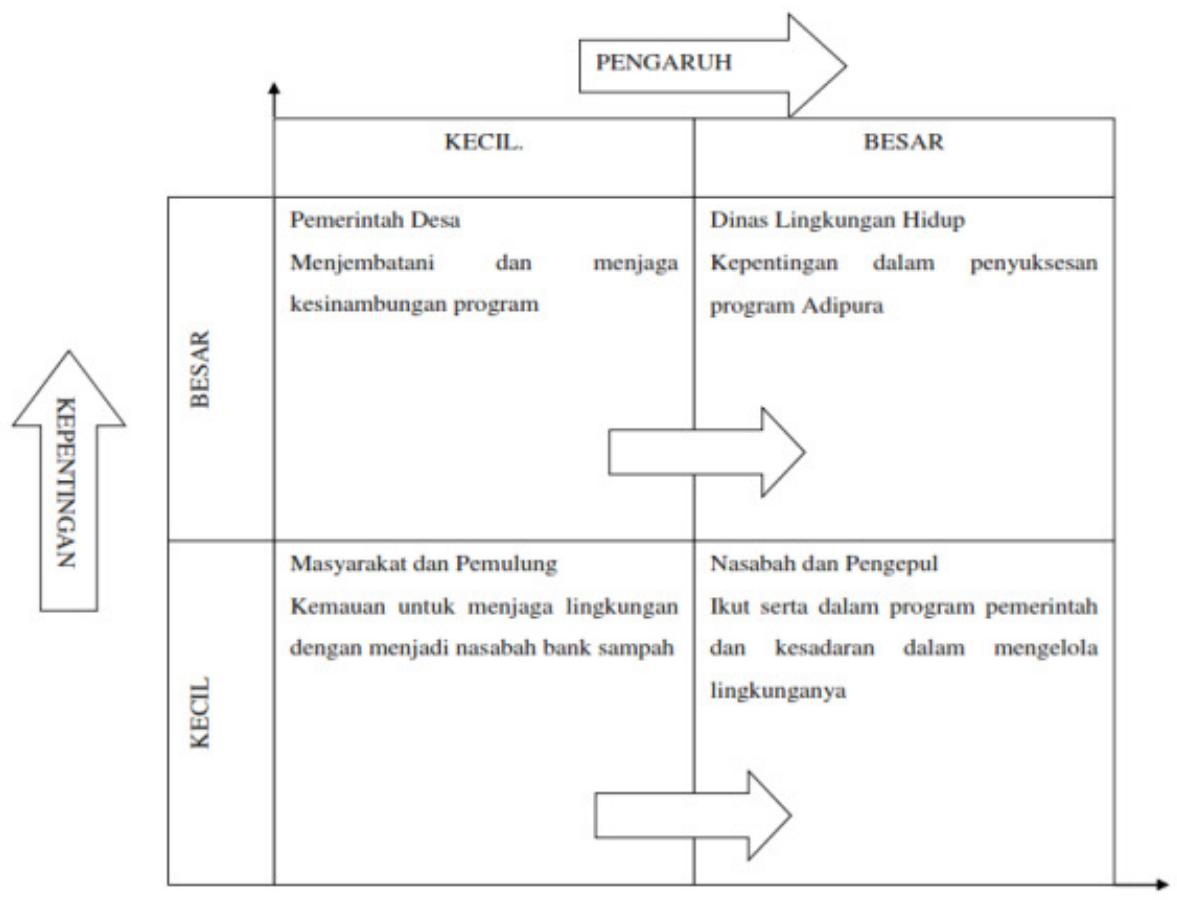

Gambar 1.

Matrik Pemangku Kepentingan (Stakeholder Mapping)

Para pemangku kepentingan yang berinteraksi dengan bank sampah dapat dibagi menjadi 4 kelompok yaitu :

(i) Kelompok yang memiliki kepentingan dan kekuatan pengaruhnya tinggi. Stakeholder yang berada pada kelompok ini adalah Dinas Lingkungan Hidup. Dinas Lingkungan Hidup Kabupaten Pati memiliki fungsi pelaksana koordinasi kepada kelompok masyarakat sekaligus melakukan pembinaan dan pelatihan teknis terkait pengelolaan sampah seperti sosialisasi peduli lingkungan, pengurangan sampah, pengomposan dan bank sampah; (ii) Kelompok yang kepentingannya tinggi dan kekuatan pengaruhnya rendah yaitu Pemerintah Desa (Pemdes). Sebagai wakil pemerintah pada tingkat desa, Pemdes berperan dalam menjembatani dan memperpendek rentang kendali pelaksanaan tugas dan fungsi pemerintah termasuk dalam pembinaan dan pengawasan terhadap penyelenggaraan urusan pemerintah pada strata pemerintah desa termasuk program DLH dalam pengelolaan sampah yaitu bank sampah;

(iii) Kelompok yang memiliki kepentingan rendah tetapi memiliki kekuatan pengaruh tinggi yaitu nasabah 
dan pengepul. Penabung atau nasabah adalah seluruh warga baik secara individual maupun kelompok, menjadi anggota penabung sampah yang dibuktikan dengan adanya kepemilikan nomor rekening, dan buku tabungan sampah dan berhak atas tabungan sampahnya;

(iv) Kelompok yang memiliki kepentingan dan kekuatan pengaruhnya rendah yaitu masyarakat dan pemulung. Bank sampah merupakan kegiatan pengelolaan lingkungan relatif bersifat top down. Hal ini membuat masyarakat menunggu program dari pemerintah, kenyataan ini tidak mendidik karena tidak mengandung unsur pengembangan inisiatif dan kreativitas.

Perubahan posisi dalam stakeholder mapping bisa dimungkinkan terjadi terutama dari Pemdes, yang awalnya pengaruhnya kecil menjadi pengaruhnya besar menggantikan Dinas Lingkungan Hidup. Kondisi ini dimungkinkan pada daerah penyangga (hinterland), ada beberapa faktor yang membuat kondisi tersebut terjadi yaitu: (a) Adanya prioritas pengembangan yang dilakukan oleh pemerintah daerah (DLH) terhadap bank sampah kota disebabkan daerah kota adalah daerah penilaian adipura; (b) Bank sampah di daerah kota sangat mandiri walaupun tanpa sokongan pemerintah desa mereka mampu berjalan, berbeda kondisinya dengan bank sampah di daerah penyangga, sokongan pemerintah desa sangat diharapkan. Dua bank sampah yang tidak aktif lagi yaitu Bank Sampah Geritan Asri dan Berani Maju terletak di daerah hinterland, dan kebetulan pemerintah desanya kurang memberikan dukungan.

Begitu juga perubahan masyarakat yang belum menjadi nasabah bisa berubah menjadi nasabah ketika ada kondisi-kondisi berikut ini a) ada beberapa anggota masyarakat yang mengharapkan uang yang diperoleh dari menjual sampah langsung dibayar tunai (cash); b) adanya inovasi dalam produk layanan dari bank sampah, salah satu bank sampah, yaitu Kusuma Harum meluncurkan program pembayaran listrik, pulsa dan tagihan lain dengan sampah.

\section{Analisis SWOT}

Berdasarkan analisis SWOT maka diperoleh faktor-faktor yang menjadi kekuatan, kelemahan, peluang dan ancaman pengelolaan bank sampah di Kabupaten Pati.

1. Kekuatan

a. Kekompakan dan semangat antar pengurus.

Kekompakan dan semangat para pengurus bank sampah sangat berpengaruh dalam kelangsungan bank sampah. Karakter dan visi pemimpin menjadi kunci dalam menjaga kekompakan dan semangat para pengurus.

b. Pemberian gaji/honor bagi pengurus Sebagian besar pengurus berpandangan kegiatan bank sampah merupakan kegiatan sosial dan berpartisipasi di bank sampah merupakan bagian kontribusi mereka dalam masyarakat. Namun demikian, adanya pemberian honor bagi pengurus pada beberapa bank sampah seperti Bank Sampah Asri Raharjo memperlancar pengelolaan bank sampah.

c. Jiwa sosial yang tinggi dan partisipasi aktif dari masyarakat

Adanya jiwa sosial dan partisipasi aktif masyarakat membuat kegiatan bank sampah masih berjalan sampai saat ini. Salah satu bentuk partisipasi masyarakat adalah dengan tetap menjadi nasabah dan menyetorkan sampah walaupun secara ekonomis menjual langsung ke pengepul lebih menguntungkan. 
d. Mempunyai fasilitas yang memadai.

Adanya fasilitas gedung, alat angkut sampah dan fasilitas angkut lainnya sangatlah membantu dalam pengembangan bank sampah. Temuan pada penelitian ini menunjukkan bahwa dengan adanya fasilitas yang memadai mampu meningkatkan pendapatan bank sampah. Fasilitas kendaraan angkut sampah membuat bank sampah tidak perlu menunggu nasabah untuk datang dan menyetor sampah namun bisa menerapkan konsep "jemput bola" dengan mendatangi rumah-rumah nasabah.

2. Kelemahan

a. Harga jual sampah tidak stabil

Kenaikan dan penurunan harga jual sampah di tingkat perusahaan berdampak penurunan daya beli berakibat pada lesunya perdagangan pada pengepul skala kecil dan perdagangan barang rongsok pada umumnya. Harga yang kurang stabil menjadikan pembelian barang rongsok menurun dan pengepul menahan sebagian rongsoknya untuk menunggu harga yang lebih stabil. Rendahnya daya beli pengepul ini berdampak pula pada bank sampah yang bertumpu pada nilai jual barang bekas/rongsok.

b. Semangat anggota dan pengurus tidak stabil.

Kesibukan pengurus menjadi faktor kendala dalam pengelolaan bank sampah, terutama terjadi pada bank sampah yang sudah berjalan selama 34 tahun. Selain semangat dalam pengelolan yang mulai menurun, kendala-kendala di lapangan yang semakin banyak, membuat banyak pengurus yang vakum.

c. Kurang kesadaran masyarakat

Dalam pengelolaan sampah, tidak seluruh warga ikut serta dalam kegiatan tersebut. Jarak yang jauh antara rumah warga dengan bank sampah membuat beberapa warga tidak ikut dalam bank sampah. Selain itu kurang sadarnya warga dalam proses pemilahan sampah juga turut menghambat keberhasilan program bank sampah.

d. Gaji/honor pengurus kurang memadai Mulai kendurnya semangat dan kesibukan pengurus yang banyak, berakibat tidak ada yang menjalankan kegiatan di bank sampah. Salah satu solusinya adalah mempekerjakan orang. Namun kemampuan bank sampah dalam memberikan gaji/honor yang layak terkendala kemampuan finansial bank sampah yang terbatas.

e. Kurangnya pendanaan

Biaya operasional yang tinggi membuat beberapa bank sampah yang umumnya berdiri di atas 3-4 tahun mulai kesulitan dalam mengelola keuangannya. Biaya operasional yang harus ditanggung pengelola bank sampah antara lain untuk biaya bahan bakar kendaraan pengangkut sampah dan untuk membayar gaji/honor pengurus maupun karyawan bank sampah. Kurangnya kemampuan pendanaan turut menghambat upaya bank sampah untuk berperan optimal dalam mengurangi jumlah sampah yang akan dikirim ke TPA.

f. Belum adanya mitra pemasaran produk kerajinan

Produk kerajinan yang mulai dikenalkan oleh DLH bekerjasama dengan ibu-ibu bank sampah sudah memberikan dampak yang baik. Pembuatan kerajinan tangan berbahan baku sampah plastik mulai banyak dilakukan oleh ibu-ibu di bank sampah. Hanya saja belum ada yang menampung khusus dan membuat show room produk kerajinan.

g. Manajemen bank sampah yang belum baik

Proses pembukuan dan transparansi dalam manajemen bank sampah menjadi kendala. Di beberapa bank 
sampah proses pencatatan yang masih manual menyulitkan dalam memantau perkembangan bank sampah.

3. Peluang

a. Membuka lapangan kerja

Dengan program bank sampah ini, diharapkan mampu membuka lapangan kerja bagi warga masyarakat. Secara langsung, bank sampah membutuhkan tenaga kerja untuk menjalankan operasional bank sampah. Dengan semakin besarnya bank sampah maka semakin banyak tenaga kerja yang dibutuhkan.

b. Masyarakat kreatif dan produktif membuat kerajinan dari limbah

Pembuatan produk kerajinan dari sampah banyak dilakukan oleh ibu-ibu dalam mengisi waktu luangnya. Proses pengubahan sampah menjadi produk mampu memberikan nilai tambah (added value) serta berpeluang untuk meningkatkan penghasilan keluarga. Menurut Asteria \& Heruman (2015), kehadiran bank sampah telah mendorong adanya capacity building bagi warga dengan mengupayakan terbentuknya kemandirian dan keswadayaan masyarakat, khususnya bagi perempuan. Pengetahuan dan keterampilan mengelola sampah telah menstimulasi kreativitas dan inovasi kerajinan.

c. Adanya dukungan dari tokoh masyarakat/Pemdes/Pemda

Pengembangan bank sampah akan lebih terintegrasi dengan adanya dukungan dari pemda setempat, tokoh masyarakat dan pengusaha lokal (Asteria \& Heruman, 2015). Bankbank sampah yang memiliki kinerja baik pada umumnya adalah bank sampah yang mendapat dukungan dari pemangku kepentingan lain.

d. Lingkungan desa jadi bersih dan sehat

Selain mendapatkan keuntungan, proses pengelolaan sampah rumah tangga juga akan membantu meningkatkan kebersihan lingkungan. Pengelolaan sampah melalui bank sampah diharapkan mampu mencegah perilaku masyarakat yang membuang sampah secara sembarangan sehingga menyebabkan lingkungan kotor dan berpotensi menimbulkan penyakit (Sidarto, 2010). Peran bank sampah dalam menciptakan lingkungan yang bersih sejalan dengan tekad Pemerintah Kabupaten Pati untuk memperoleh penghargaan Adipura.

e. Meningkatkan pendapatan

Menurut Melyanti (2014), adanya pengelolaan sampah dengan bank sampah menambah pendapatan masyarakat.

4. Ancaman

a. Bencana Banjir

Beberapa bank sampah terletak pada daerah yang sering dilanda banjir. Terjadinya banjir selain menghentikan aktivitas di bank sampah juga menyebabkan kerusakan pada aset-aset bank sampah.

b. Sampah dimakan binatang pengerat

Beberapa jenis sampah misalnya sampah organik menarik bagi binatang pengerat. Tidak baiknya penataan sampah dan kurang bersihnya lingkungan bank sampah (housekeeping) menjadikan lingkungan bank sampah menjadi kumuh dan menjadi sarang binatang pengerat.

c. Adanya pemulung/pengepul yang menjadi saingan

Adanya pengepul/pemulung yang datang ke rumah-rumah membuat para nasabah yang ingin mendapat uang tunai, lebih menjual sampahnya ke pemulung/pengepul. Selain itu, nasabah yang mempunyai sampah dalam jumlah besar lebih memilih membawa sampah ke pengepul langsung. Selain mendapatkan uang 
tunai, mereka tidak dikenakan pemotongan untuk biaya operasional seperti di bank sampah.

\section{Strategi Pengembangan}

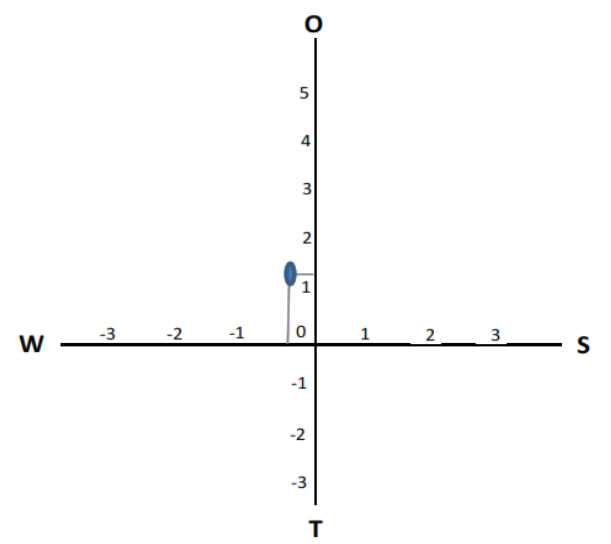

Gambar 2.

Diagram Kuadran Strategi

Berdasarkan analisis SWOT terhadap faktor internal dan eksternal diperoleh koordinat kebijakan pengembangan bank sampah berada di kuadran III (negatif, positif) seperti terlihat pada Gambar 2. Rekomendasi strategi yang diberikan adalah Ubah Strategi, artinya organisasi disarankan untuk mengubah strategi sebelumnya. Sebab, strategi yang lama sulit untuk dapat menangkap peluang sekaligus memperbaiki kinerja organisasi.

Berdasarkan penilaian pada setiap faktor internal dan eksternal pada analisis SWOT maka dapat dilakukan alternatif strategi sebagai berikut:

(a) Strategi kombinasi antara kekuatan dan peluang (S-O). Strategi ini menggunakan seluruh kekuatan untuk memanfaatkan peluang. Adapun strategi yang dapat diterapkan adalah (1) berupaya untuk menggandeng Pemdes sehingga bank sampah menjadi kegiatan unggulan desa; (2) berupaya mendorong anggota untuk membuat kerajinan;

(b) Stategi kombinasi antara kekuatan dan Ancaman (S-T). Strategi ini menggunakan seluruh kekuatan yang dimiliki dengan menghindari ancaman. Strategi yang masuk dalam kelompok ini adalah (1) menjadikan pemulung menjadi mitra dalam pengelolaan sampah dengan menariknya menjadi nasabah; (2) mendesak Pemdes dan DLH menyediakan sarana dan prasarana pendukung;

(c) Strategi kombinasi antara peluang dan kelemahan (W-O). Strategi ini diterapkan berdasarkan peluang yang ada dengan mengatasi kelemahan. Strategi yang dijalankan adalah mendesak DLH untuk : (1) memberikan pelatihan untuk para pengelola maupun calon pengelola bank sampah; (2) menampung dan membeli produk kerajinan sampah; (3) melakukan sosialisasi bersama Pemdes terkait pengelolaan sampah dan pengoptimalan kinerja dalam keuangan. Bank sampah dapat membuat inovasi produk layanan sampah, membuka usaha simpan pinjam atau usaha yang lain agar pendapatannya meningkat sehingga memungkinkan untuk memberikan tunjangan bagi pengurus maupun mempekerjakan orang lain.

(d) Strategi kombinasi antara kelemahan dan Ancaman (W-T), strategi ini digunakan untuk meminimalkan kelemahan serta menghindari ancaman. Strategi pertama yaitu menempatkan bank sampah di tempat fasilitas umum bukan bertempat di rumah pengurus. Lokasi bank sampah di rumah pengurus dapat menimbulkan rasa sungkan bagi para nasabah selain dikhawatirkan menumpuknya sampah membuat bibit penyakit datang. Strategi kedua yaitu mendesak DLH untuk merealisasikan bank sampah induk, sehingga masalah harga yang sering dipermainkan oleh pemulung bisa teratasi.

\section{KESIMPULAN DAN SARAN}

\section{Kesimpulan}

Tingkat keberlanjutan bank sampah Kabupaten Pati, berada pada 
angka $60 \%$ yang berarti sistem bank sampah dianggap wajar tapi menunjukan ada ruang yang besar untuk improvement dalam program bank sampahnya. Berdasarkan stakeholder mapping terdapat 6 kelompok yang berpengaruh dan berkepentingan terhadap bank sampah yaitu DLH, Pemerintah Desa, nasabah, pengepul, pemulung dan masyarakat. Perlu upaya inovatif dan partisipatif dari pengelola bank sampah untuk mendorong pemerintah desa dan masyarakat untuk mendukung penuh kegiatan bank sampah.

Strategi yang dapat digunakan dalam pengembangan bank sampah berdasarkan analisis SWOT adalah 2 strategi (S-O), 3 strategi (W-O), 2 strategi (S-T) dan 2 strategi (W-T). Strategi utamanya adalah mendorong DLH untuk memberikan pelatihan, siap menampung dan membeli produk kerajinan sampah serta melakukan sosialisasi bersama Pemdes terkait.

\section{Saran}

Perlu dilakukan kajian lebih mendalam mengenai tahapan pengorganisasian bank sampah. Dengan mengenal pengelolaan bank sampah lebih detail maka kita bisa memberikan saransaran penyelesaian lebih mendetail terhadap pengembangan bank sampah. Mendorong Pemerintah Desa untuk mendukung penuh baik dari segi dukungan kebijakan dan pendanaan yang masuk Anggaran Pendapatan dan Belanja Desa (APBDes) dalam pengembangan bank sampah. Selain bisa mendatangkan pendapatan desa, program bank sampah membuat lingkungan desa lebih bersih.

\section{DAFTAR PUSTAKA}

Abadi, R. S. (2013). Keberlanjutan pengelolaan sampah domestik di Kampung Menoreh, Kelurahan Sampangan,
Pembangunan Wilayah \& Kota, 9(1), 87-96.

Anggraini, A. D. Noor, I., Said, A. (2015). Strategi Inovatif Pengelolaan Sampah Rumah Tangga Perkotaan (Studi Pada Bank Sampah "Sri Wilis" Perum Wilis II Kelurahan Pojok Kecamatan Mojoroto Kota Kediri). Administrasi Publik, 3(11), 18371843.

Apriliyanti, P. D. Soemarno., Meidiana, C. (2015). Evaluasi Kinerja Bank Sampah Kartini Mandiri Desa Pesanggrahan Kota Baru. J-PAL, 6(2), 143-152.

Asteria, D., Heruman, H. (2016). Bank Sampah sebagai alternatif strategi pengelolaan sampah berbasis masyarakat di Tasikmalaya. Manusia dan Lingkungan, 23(1), 136-141.

Herdiansyah, H. (2010). Metodologi Penelitian Kualitatif. Jakarta: Salemba Humanika.

Kristina, H. J. (2014). Model Konseptual Untuk Mengukur Adaptabilitas Bank Sampah di Indonesia. J@TI Undip, 9(1).

Mallongi, A. \& Saleh, M. (2015). Pengelolaan Limbah Padat Perkotaan. Makasar: Writing Revolution.

Melyanti I. M. (2014). Pola kemitraaan Pemerintah, Civil Society, dan swasta dalam Program Bank Sampah di Pasar Baru Kota Probolinggo. Jurnal Kebijakan dan Manajemen Publik, 2(1).

Mustofa, H. A. (1997). Kamus Lingkungan. Solo: Rineka Cipta Jakarta

Peraturan Menteri Negara Lingkungan Hidup Republik Indonesia Nomor 
13 Tahun 2012 tentang Pedoman Pelaksanaan Reduce, Reuse, dan Recycle Melalui Bank Sampah. (2012). Jakarta.

Purwanti, W. S. Sumartono., Haryono, B. S. (2015). Perencanaan Bank Sampah dalam rangka Pemberdayaan Masyarakat di Kecamatan Kepanjen Kabupaten Malang. Jurnal Reformasi, 5(1)

Sidarto. (2010). Analisis Usaha Proses Pengelolaan Sampah Rumah Tangga dengan Pendekatan Cost and Benefit guna menunjang Kebersihan Lingkungan. Jurnal Teknologi, 3(2)

Sucipto, C. D. (2012). Teknologi Pengolahan Daur Ulang Sampah. Pontianak: Goysen Publishing.

Suharto, E. (2005). Membangun Masyarakat Memberdayakan
Rakyat. Bandung: PT. Refika Aditama.

Suwerda, B. (2012). Bank Sampah, Kajian Teori dan Penerapannya. Yogyakarta: Pustaka Rihama.

Usman, H., Akbar, P. S. (2009). Metodologi Penelitian Sosial. Jakarta: Penerbit Bumi Aksara

Utami, E. (2013). Buku Panduan Sistem Bank Sampah dan 10 Kisah Sukses. Jakarta: Unilever Indonesia.

\section{BIODATA PENULIS}

Iwan Riswana, dilahirkan di Kota Tangerang, Banten pada tanggal 25 April 1982. Memperoleh gelar Sarjana (S1) dari Universitas Lampung. Gelar S2 diperoleh dari Universitas Hasanuddin Makasar pada Program Studi Perencanaan Pengembangan Wilayah. Saat ini bekerja pada Dinas Lingkungan Hidup Kabupaten Pati. 